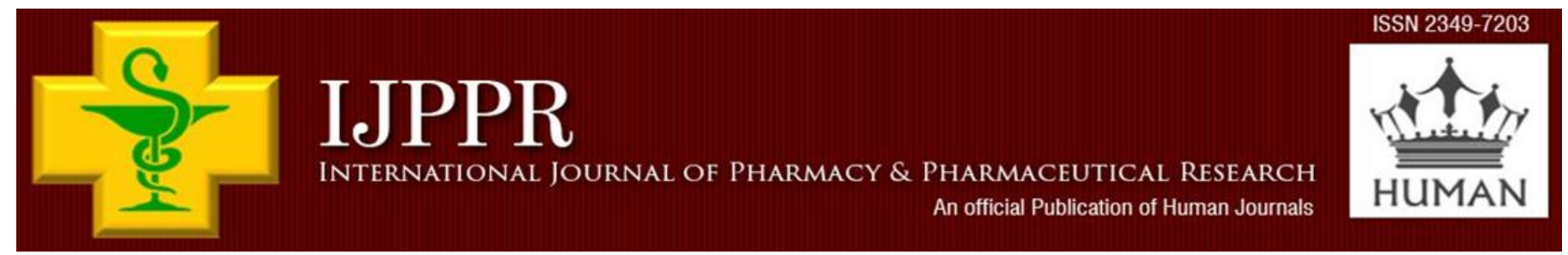

Human Journals

Review Article

September 2020 Vol.:19, Issue:2

(C) All rights are reserved by Sachin Aryal et al.

\title{
Lipid Based Drug Delivery System: An Approach to Enhance Bioavailability of Poorly Water Soluble Drugs
}

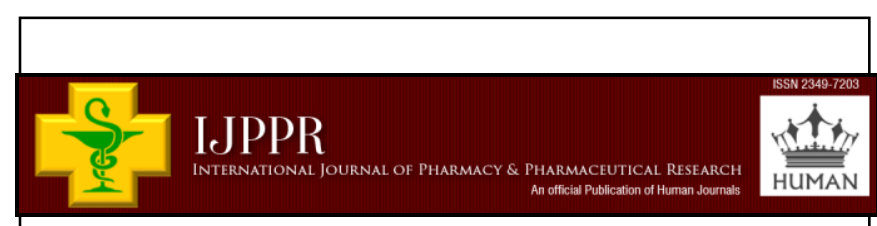

Sachin Aryal*, Roshan Gyawali, Yuvraj Regmi, Beny Baby

Department of pharmaceutics, Karnataka College of Pharmacy, Bangalore 560064 India

Submission: 25 August 2020

Accepted: $\quad 31$ August 2020

Published: $\quad 30$ September 2020
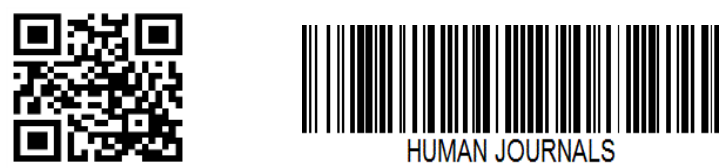

www.ijppr.humanjournals.com
Keywords: Lipid-based drug delivery system; Lipid digestion; Lipid excipients; Solubilization; Lymphatic absorption; Bioavailability

\section{ABSTRACT}

The novel drugs recently discovered are mostly lipophilic, and they show low oral bioavailability due to less solubility and poor gastrointestinal absorption. Consequently, the formulation of low aqueous soluble drugs is challenging for the formulation scientist. Among various innovative approaches to enhance drug bioavailability, the lipid-based drug delivery system is one of the promising and novel approaches to increase drug bioavailability, especially of oral formulations. Various lipid excipients that are approved by the FDA have typically been used in the lipid-based formulations which adequately provide assurance that the formulations are safe and effective to use. The specific mechanism involves in the lipid drug delivery system is lipid digestion so the lipid used in the formulation should be biodegradable. Therefore the present review is principally focused on the formulation approach of the lipidbased drug delivery system along with its characterization. The review also focuses on the practical guidelines to design formulations, regulatory aspects, and potential applications of the lipid-based drug delivery system. 


\section{www.ijppr.humanjournals.com}

\section{INTRODUCTION:}

Most of the drugs which are recently discovered are hydrophobic, and they show low bioavailability when administered through oral route [1]. Also, the newly discovered drugs are not suitable for oral delivery [2] because the new chemical entities discovered are having high molecular weight and increasing lipophilicity [3-6]. Accordingly, the poor aqueous solubility of lipophilic drugs has become a problem in drug discovery as well as the formulation and development of such drugs. It was evident that about $40 \%$ of currently marketed drugs and up to $70 \%$ of compounds recently under development are suggested to be poorly aqueous soluble [7-9]. Due to low aqueous solubility insufficient amount of drugs reaches the systemic circulation followed by the site of action which lacks the pharmacological action and poor bioavailability [10].

The poor aqueous solubility and low dissolution rate limit the oral bioavailability. Hence, the formulation of these therapeutic agents is a challenging task to deliver the drug through the oral route with maximum oral bioavailability. The efficacy of the drug is also indicated by the rate and extent of drug absorption through the GI membrane which is only possible when the maximum percentage of drugs gets solubilized in GI contents [11]. In Biopharmaceutics Classification System (BCS) the drugs are classified into four classes according to their aqueous solubility and GI membrane permeability. The class II drugs (low solubility and high permeability) and class IV drugs (low solubility and low permeability) are considered as challenging for the formulation to enhance bioavailability [12].

The low aqueous solubility of various drugs not only leads to poor bioavailability but equally affects dose proportionality in between the subjects [13]. Some of the drugs like Halofentrine [14], danazol [15] are evident to enhance bioavailability when co-administered with foods. There should be a proper balance between bioavailability, toxicity, and drug disposition within the body to assure that the formulated drug is safe and efficacious [16]. Numerous bioavailability enhancement techniques like solid dispersions, micronization, and complexation with cyclodextrin, permeation enhancers, and surfactants have been put forwarded to solve the problems of solubility and permeability [17]. Among the various techniques that come into practice from the recent 15 years, the Lipid-based Delivery System (LBDDS) has gained considerable research in pharmaceutical research [18, 19].

The present review focuses on the various approaches of the LBDDS for the enhancement of bioavailability of drugs having low aqueous solubility. 


\subsection{Lipid-based Drug Delivery System:}

Lipid-based drug delivery was put forward when it was recognized that the bioavailability of low aqueous soluble drugs like cyclosporine A (Sandimune neural ${ }^{\circledR}$ ), Saquinavir $\left(\right.$ Fortovase $^{\circledR}$ ), and Ritonavir (Norvir ${ }^{\circledR}$ ) increased when co-administered with a fat-rich meal $[20,21]$. In the last few years, it is reported that lipids are used as carriers for poorly watersoluble drugs [22]. Due to the ability of lipids to improve the solubility and bioavailability of poorly water-soluble drugs, the lipid-based drug delivery system has gained much interest in recent years [23]. It is reported that lipid-based carriers are found to be safe and efficient due to which they are used as an attractive candidate for the formulation of pharmaceuticals, vaccines, diagnostics, and nutraceuticals [24]. Lipid-based drugs can be delivered through different routes like oral, parenteral, ocular, intranasal, transdermal, and veginal. However, due to noninvasiveness and cost-effectiveness, the oral route is highly favored $[25,26]$. Lipid-based formulations procedure is involved in different dosage forms like oil solution, oil suspension, emulsions, self-micro emulsifying drug delivery system, self nano-emulsifying drug delivery system, and solid lipid-based drug delivery system [27, 28].

The physicochemical properties of the drug are very important in the formulation of the lipidbased formulations for the in-vivo performance of the drug. Since the drug is generally solubilized in the lipid-based drug delivery system, the dissolution step can be escaped. This is the advantage for formulator but if solubilization capacity is lost when aqueous dilution and dispersion and once precipitate then it is assumed that re-dissolution is too slow as compared to the intestinal transit time [29]. For better access to such issues physiologically based modeling is very helpful which considers drug release and precipitation dynamically together with re-dissolution and absorption [30, 31].

When the drug itself acts oil-like properties (e.g. tocopherol nicotinate, teprenone) they are formulated as a lipid-based drug delivery system [32]. The lipid-based system is composed of a simple or complex mixture of oils, surfactants, co-solvents, etc. based on the formulation variables [33]. In vivo performance of lipid-based drug delivery system is determined by the composition of the lipid-based formulations, so the number of parameters should be well understood for the development of the successful lipid-based formulations [34, 35]. 
www.ijppr.humanjournals.com

\subsection{Lipid-based Drug Delivery: Classification System}

Lipid-based formulation implies different systems including solutions, emulsions, micellar systems, self-emulsifying drug delivery systems and self-micro emulsifying drug delivery systems. Pouton [36] suggested a lipid classification system as mention in table 1 which classified different formulation into four classes.

Table No. 1: Lipid formulation classification system with reference to pouton [36]

\begin{tabular}{|c|c|c|c|c|}
\hline \multicolumn{5}{|c|}{ Excipients in formulations $(\% \mathrm{w} / \mathrm{w})$} \\
\hline & $\begin{array}{l}\text { Oils: } \\
\text { triglycerides } \\
\text { or mixed } \\
\text { monoglycerides } \\
\text { and di-glycerides }\end{array}$ & $\begin{array}{l}\text { Hydrophobic } \\
\text { surfactants } \\
\left(\text { HLB }^{*}<12\right)\end{array}$ & $\begin{array}{l}\text { Hydrophilic } \\
\text { surfactants } \\
(\text { HLB > 12) }\end{array}$ & $\begin{array}{l}\text { Hydrophilic } \\
\text { co-solvents } \\
\text { (e.g. } \\
\text { PEG, glycerol, } \\
\text { ethanol) }\end{array}$ \\
\hline Type I & 100 & - & - & - \\
\hline Type II & $40-80$ & $20-60$ & - & - \\
\hline Type IIIA & $40-80$ & - wites & $20-40$ & $0-40$ \\
\hline Type IIIB & $<20$ & & $20-50$ & $20-50$ \\
\hline Type IV & 0 & $0-20$ & $30-80$ & $0-50$ \\
\hline
\end{tabular}

*HLB = Hydrophilic Lipophilic Balance. 
Table No. 2: Characteristics of different type of lipid classes classified by the lipid classification system

\begin{tabular}{|c|c|c|c|c|c|}
\hline $\begin{array}{c}\text { Types/characteri } \\
\text { stics }\end{array}$ & Dispersibility & Digestibility & $\begin{array}{c}\text { Initial } \\
\text { solvent } \\
\text { capacity }\end{array}$ & $\begin{array}{c}\text { Solvent } \\
\text { capacity } \\
\text { upon } \\
\text { dispersion }\end{array}$ & $\begin{array}{c}\text { Solvent } \\
\text { capacity } \\
\text { upon } \\
\text { Digestion }\end{array}$ \\
\hline $\mathbf{I}$ & $\begin{array}{c}\text { Pure oil } \\
\text { Limited or no } \\
\text { dispersion }\end{array}$ & Digestible & Poor & $\begin{array}{c}\text { No } \\
\text { impact }\end{array}$ & Increased \\
\hline II & $\begin{array}{l}\text { SEDDS* } \\
\text { Mild dispersion with } \\
\text { the absence of } \\
\text { hydrophilic } \\
\text { components }\end{array}$ & $\begin{array}{l}\text { probably to be } \\
\text { digestible }\end{array}$ & Intermediate & No impact & Possible loss \\
\hline IIIA & $\begin{array}{c}\text { SMEDDS** } \\
\text { Fast dispersion in } \\
\text { presence of } \\
\text { hydrophilic } \\
\text { components to form } \\
\text { micro/nanoemulsion } \\
\text { s }\end{array}$ & Maybe digestible & $\begin{array}{c}\text { Slightly } \\
\text { above } \\
\text { intermediate }\end{array}$ & $\begin{array}{l}\text { Possible } \\
\text { loss }\end{array}$ & Possible loss \\
\hline IIIB & $\begin{array}{l}\text { SMEDDS } \\
\text { Very fast dispersion } \\
\text { in presence of } \\
\text { hydrophilic and low } \\
\text { oil to form } \\
\text { micro/nanoemulsion }\end{array}$ & Poorly digestible & High & $\begin{array}{l}\text { Possible } \\
\text { loss }\end{array}$ & Possible loss \\
\hline IV & $\begin{array}{l}\text { Oil-free } \\
\text { Rapid dispersion } \\
\text { forming a micellar } \\
\text { solution }\end{array}$ & Not digestible & High & $\begin{array}{l}\text { Likely } \\
\text { loss }\end{array}$ & No impact \\
\hline
\end{tabular}

*SEDDS $=$ Self emulsifying Drug delivery system, **SMEDDS= Self micro emulsifying drug delivery system 
Different types of lipid classes have different properties as mentioned in table 2. Type I lipidbased formulation contains oils like triglycerides or a mixture of di and monoglycerides which must be digested to facilitate the drug absorption within the gastrointestinal tract. Type I formulation is simple and biocompatible which shows that they are safe listed excipient. In the case of type, I formulation lipid digestion makes not lose the solubilization capacity after dispersion and digestion. This indicates that there are no possibilities of precipitation and loss of bioavailability. Type II lipid-based formulation is composed of a mixture of lipids and water-insoluble surfactants $(\mathrm{HLB}<12)$ which on contact with gastrointestinal fluids undergoes emulsification $(\mathrm{o} / \mathrm{w})$. The pancreatic lipase can interact and leads to faster digestion than type I lipid-based formulation due to the high surface area. Depending on the surfactant there may be loss of the salvation capacity after digestion. Type III lipid-based formulations (class IIIA and IIIB) includes water-soluble surfactants (HLB>12) and cosolvents. When these formulations come in contact with gastrointestinal fluids, they undergo self-emulsification (i.e. SEDDS when the system is milky emulsion) having the droplet size greater than $200 \mathrm{~nm}$ or SMEDDS when a transparent emulsion is formed with less globular size. The type IV formulations do not contain oil which is based on water-soluble surfactants and co-solvents. When these components get dispersed in the aqueous medium then fine dispersions are formed which leads to rapid drug release and absorption. Hence, during dispersion, there is a risk of precipitation in the gastrointestinal tract [37].

\section{Excipients for lipid-based formulation:}

The formulation and development should always start with the selection of various excipients. Hence, for the formulation of LBDDS, many lipids based substances can be used. Some general formulation parameters are mentioned in table 3. 
Table No. 3: Formulation parameters affecting the bioavailability of drugs from LBDDS

\begin{tabular}{|c|c|}
\hline Factor & Explanations \\
\hline Lipid digestion & $\begin{array}{l}\text { If a drug is highly lipophilic then, it can be supposed that the } \\
\text { drug moves through GIT incorporated into the lipids droplets } \\
\text { which indicate that the digestibility of the lipid relates to gastric } \\
\text { emptying time [38]. } \\
\text { The type and concentration of surfactants used to affect the size } \\
\text { of droplets in SEDDS and SMEDDS i.e. higher the } \\
\text { concentration of surfactant, the smaller the emulsion droplet and } \\
\text { the faster the drug release [39]. }\end{array}$ \\
\hline $\begin{array}{l}\text { Mean emulsion droplet } \\
\text { size }\end{array}$ & $\begin{array}{l}\text { The emulsion formed spontaneously indicates the drug } \\
\text { dissolved form. Thus formed small droplets provide a large } \\
\text { surface area. These characteristics result from an increase in } \\
\text { drug release which may be independent of gastrointestinal } \\
\text { physiology [40]. } \\
\text { The emulsion droplets formed may be positively or negatively } \\
\text { charged. Since the mucosal lining is negatively charged, the } \\
\text { cationic droplets are entrapped dipper inside the mucous } \\
\text { membrane resulting in greater bioavailability then anionic } \\
\text { droplets [41, 42]. }\end{array}$ \\
\hline Lipophilicity of the API & $\begin{array}{l}\text { Highly hydrophobic drugs }(\log \mathrm{p}>5) \text { can be taken up into the } \\
\text { lymphatic system by partitioning into chylomicron and avoid } \\
\text { first-pass metabolism [43]. }\end{array}$ \\
\hline Chemistry of lipids & $\begin{array}{l}\text { It was reported that formulation having long-chain triglycerides } \\
\text { shows increased bioavailability than using medium-chain } \\
\text { triglycerides }[44,45] \text {. }\end{array}$ \\
\hline
\end{tabular}




\section{Lipid excipients:}

Various factors influencing the bioavailability, texture, and acceptability of LBDDS include miscibility, solvent capacity, self-dispersibility, digestibility, and regulatory issues like irritancy, toxicity, purity, chemical stability. To prepare the lipid-based formulations various dietary oils along with different permeation enhancers are used [46, 47]. Many lipids are reported to be amphiphilic which has the lipophilic portion and a hydrophilic portion [48].

Different solubilizing agents used in the lipid-based formulation are mentioned in table 4.

Table No. 4: Solubilizing excipients used in commercially available lipid-based formulations [49]

\begin{tabular}{|c|c|c|}
\hline Water insoluble excipients & $\begin{array}{l}\text { Water soluble } \\
\text { excipients }\end{array}$ & Surfactants \\
\hline Beeswax, & Ethanol & $\begin{array}{l}\text { Polysorbate } 20 \\
\text { Polysorbate } 80\end{array}$ \\
\hline Oleic acid, & Glycerin & Sorbitan mono laurate \\
\hline Soya fatty acid, & Dimethyl sulfoxide & $\begin{array}{l}\text { D- } \alpha-\text {-Tocopheryl } \\
\text { PEG1000 succinate }\end{array}$ \\
\hline D- $\alpha$-Tocopherol(vitamin E), & PEG 300 & $\begin{array}{l}\text { (TPGS), } \\
\text { Glyceryl monooleate, }\end{array}$ \\
\hline Corn oil mono-di-triglycerides, & PEG 400 & \\
\hline $\begin{array}{l}\text { Medium-chain (C8/C10)mono and di- } \\
\text { glycerides, }\end{array}$ & $\begin{array}{l}\text { Propylene glycol } \\
\text { Poloxamer } 407\end{array}$ & $\begin{array}{l}\text { Polyoxyl } 40 \text { hydrogenated } \\
\text { castor oil }\end{array}$ \\
\hline $\begin{array}{l}\text { Long-chain triglycerides } \\
\text { Castor oil }\end{array}$ & $\begin{array}{l}\text { Hydroxypropyl- } \beta- \\
\text { cyclodextrin }\end{array}$ & $\begin{array}{l}\text { (cremophorRH40), } \\
\text { Polyoxyl } 60 \text { hydrogenated } \\
\text { castor oil } \\
\text { (cremophorRH60), }\end{array}$ \\
\hline Corn oil & $\alpha$-cyclodextrin & PEG 300 oleic glycerides \\
\hline Olive oil & phospholipids & PEG 300 linoleic \\
\hline Peanut oil & & $\begin{array}{l}\text { glycerides (Labrafils } ® \text { M- } \\
2125 \mathrm{CS} \text { ), }\end{array}$ \\
\hline Sesame oil & & PEG 400 caprylic/Capric \\
\hline Soybean oil & & $\begin{array}{l}\text { Glycerides (Labrasols®), } \\
\text { PEG } 1500 \text { lauric }\end{array}$ \\
\hline Coconut oil & & $\begin{array}{l}\text { glycerides (Gelucires® } \\
\text { 44/14). }\end{array}$ \\
\hline
\end{tabular}




\section{Types of lipid excipients:}

\section{a. Triglycerides:}

Triglyceride vegetable oils that do not show any safety issues are the most commonly used excipients in the lipid-based formulations [50]. Triglycerides are naturally divided into longchain triglycerides(LCT), medium-chain triglycerides(MCT), and short-chain triglycerides(SCT). The concentration of the ester group present in lipids determines the solvent capacity [51]. MCT possesses greater solvent capacity than LCT which is also less prone to oxidation [52].

\section{b. Mixed glycerides and polar oils:}

On partial hydrolysis of vegetable oil, mixed glycerides are obtained. The chemical composition of mixed glycerides depends on the starting materials and extent of hydrolysis. Medium-chain mixed glycerides do not undergo oxidation and have a greater solvent capacity which promotes emulsification. Sorbitan trioleate (span 85) which is polar oil improves solvent capacity and dispersibility of the formulation [53, 54].

\section{c. Cosolvents:}

Cosolvents are used in formulation to increase the solubilization process [55]. Different popular cosolvents used are ethanol, glycerol, propylene glycol, and polyethylene glycol. They increase the solvent capacity and enhance the dispersion of the system. However, on aqueous dilution, there is a loss of solvent capacity which leads to precipitation of the solubilized drug [56].

\section{d. Water-insoluble surfactants:}

The lipid excipients with HLB values between 8 and 12 comes under this category. These surfactants can form micelles but are not able to self emulsify due to insufficiently hydrophilic nature. Examples of water-insoluble surfactants include Sorbitan trioleate (tween 85 ) and glyceryl trioleate (tarot-TO) [57, 58].

\section{e. Water-soluble surfactants:}

These surfactants are commonly used surfactants in a self-emulsifying drug delivery system [59]. These excipients are synthesized by mixing polyethylene glycol with hydrolyzed vegetable oil. Cremophor RH40 and RH60 (ethoxylated hydrogenated castor oil) are prime 
examples of water-soluble surfactants. They are obtained from the chemical hydrogenation of organic materials derived from vegetable oils. Cremophor is reported to enhance absorption by inhibiting the efflux pump [60, 61].

\section{Formulation approaches of lipid-based drug delivery system:}

By considering the formulation objectives of the lipid-based drug delivery system can be developed successfully. The names of commercially available lipid-based drugs are tabulated in table 5. There are various approaches for the lipid-based drug delivery system which are discussed below.

\section{a. Oily liquids:}

Highly lipophilic drugs (e.g. steroids) are soluble in oil only, so these drugs have to be formulated as oily liquids. An oily solution of bupivacaine, a free base was prepared by using a mixture of fractioned coconut oil (viscoleo®) and coconut oil [62].

\section{b. Mixed micelles:}

The systems resemble a lipid bilayer which is a disc-like structure. In detergent-lipid mixed micelle, the lipid molecule is shielded by detergent to protect against water on the surface. The activity of paclitaxel and parthenolide was reported to be increased against taxol-resistant and sensitive lung cancer cell line when co-encapsulated in mixed micelle of PEG 2000 distearyl phosphatidylethanolamine (DSPE) and Vitamin E TPGS [63].

\section{c. Self-emulsifying system:}

Due to the presence of different surfactants in the oily phase, the system can emulsify. The lipophilic drug is solubilized in the oil phase and surfactants used help in the dispersion of the oily phase in GI fluid. The formulation of a self-emulsifying system is generally composed of the drug, oily vehicle, surfactant, co-surfactant, and co-solvent [64]. It was reported that SMEDDS sustained-release pellets of puerarin were formulated using castor oil as oil phase, Cremophor®EL as an emulsifier, and 1,2-propanediol as the co-emulsifier for oral administration [65].

\section{d. Liposomes:}

Liposomes are spherical bilayer which adequately reflects the cell membrane in their structural arrangement. Phospholipids that are being amphiphilic are used in liposomes 
formation. These phospholipids when undergo hydration in water forms spherical bilayer structure [66]. Because of the unique formation of this complex structure, hydrophilic substances can be embedded into the aqueous internal space of the globule whereas hydrophobic drugs can be solubilized within the inner fatty acid layer. Propylene glycol liposomes loaded with epirubicin having enhanced permeability to both the healthy cell membrane and nuclear membrane of the tumor cell is reported to overcome multidrug resistance in Breast cancer [67].

\section{e. Solid lipid nanoparticles:}

Solid lipid nanoparticles are spherical particles (size range $10-1,000 \mathrm{~nm}$ ) containing solid lipid core matrix which is stabilized by surfactants that can solubilize the lipophilic molecule [68]. Lipids which are used in solid lipid nanoparticle are monoglycerides (e.g. glycerol monostearate), di-glycerides (e.g. glycerol behenate), triglycerides (e.g. tristearin), steroids (e.g. Cholesterol), fatty acids (e.g. stearic acid), and waxes (e.g. cetyl palmitate). It is reported that the oral bioavailability of carvedilol was increased by formulating carvedilol solid lipid nanoparticles coated with a polymer (N-carboxymethyl chitosan) [69].

Table No. 5: Examples of FDA approved lipid-based products [70]

\begin{tabular}{|c|c|c|c|c|}
\hline $\begin{array}{c}\text { Molecules/trade } \\
\text { name }\end{array}$ & $\begin{array}{c}* \text { NDA } \\
\text { year }\end{array}$ & $\begin{array}{c}* * * \mathrm{BCS} \\
\text { classification }\end{array}$ & $\begin{array}{c}* * * * \mathrm{LFC} \\
\text { system }\end{array}$ & Drug category \\
\hline $\begin{array}{c}\text { Cyclosporin A } \\
(\text { Gengraf } \AA)\end{array}$ & 2000 & 2 & IV & $\begin{array}{l}\text { Calcineurin } \\
\text { inhibitor }\end{array}$ \\
\hline $\begin{array}{c}\text { Ritonavir/lopinavir } \\
\text { (KaletraVR ) } \\
\text { Discontinued }\end{array}$ & 2000 & 4 & III & $\begin{array}{l}\text { Protease } \\
\text { inhibitors }\end{array}$ \\
\hline $\begin{array}{l}\text { Dutasteride } \\
\text { (Avodart®) }\end{array}$ & 2001 & $2 / 4$ & I & $\begin{array}{l}5 \text { alpha- } \\
\text { reductase } \\
\text { inhibitor }\end{array}$ \\
\hline $\begin{array}{l}\text { Isotretinoin } \\
\text { (Claravis } ®)\end{array}$ & $\begin{array}{c}2003 \\
(* * \text { ANDA })\end{array}$ & 2 & I & Retinoid \\
\hline $\begin{array}{l}\text { Omega-3-acid ethyl } \\
\left.\text { esters (Lovaza }{ }^{\circledR}\right)\end{array}$ & 2004 & & I & Lipid regulation \\
\hline
\end{tabular}


www.ijppr.humanjournals.com

\begin{tabular}{|c|c|c|c|c|}
\hline $\begin{array}{l}\text { Tipranavir } \\
\left.\text { (Aptivus }{ }^{\circledR}\right)\end{array}$ & 2005 & 4 & IIIA & $\begin{array}{l}\text { Protease } \\
\text { Inhibitor }\end{array}$ \\
\hline $\begin{array}{l}\text { Tipranavir } \\
\text { (Aptivus@) }\end{array}$ & 2005 & 4 & IV & $\begin{array}{l}\text { Protease } \\
\text { Inhibitor }\end{array}$ \\
\hline $\begin{array}{l}\text { Paricalcitol } \\
\text { (Zemplar®) }\end{array}$ & 2005 & 4 & $\mathrm{I}$ & $\begin{array}{c}\text { Vitamin D } \\
\text { Analog }\end{array}$ \\
\hline $\begin{array}{l}\text { Lubiprostone } \\
\text { (Amitiza®) }\end{array}$ & 2006 & $2 / 4$ & I & $\begin{array}{c}\text { Chloride channel } \\
\text { Activator }\end{array}$ \\
\hline $\begin{array}{l}\text { Fenofibrate } \\
\text { (Lipofen®) }\end{array}$ & 2006 & 2 & III & $\begin{array}{l}\text { Peroxisome } \\
\text { proliferator } \\
\text { activated } \\
\text { receptor } \alpha \\
\text { (PPAR } \alpha) \\
\text { Activator }\end{array}$ \\
\hline $\begin{array}{c}\text { Topotecan } \mathrm{HCl} \\
\text { (Hycamtin } ®)\end{array}$ & 2007 & 1 & I & $\begin{array}{c}\text { Topoisomerase } \\
\text { Inhibitor }\end{array}$ \\
\hline $\begin{array}{l}\text { Loratadine } \\
\text { (Claritin } ®)\end{array}$ & 2008 & 2 & & Antihistamine \\
\hline $\begin{array}{l}\text { Isotretinoin } \\
\text { (Absorica } ® \text { ) }\end{array}$ & 2012 & 2 & & Retinoid \\
\hline $\begin{array}{c}\text { Enzalutamide } \\
\text { (Xtandi®) }\end{array}$ & 2012 & 2 & 1 & $\begin{array}{l}\text { Androgen } \\
\text { receptor } \\
\text { inhibitor }\end{array}$ \\
\hline Nintedanib (Ofev®) & 2014 & $2 / 4$ & II & $\begin{array}{c}\text { Tyrosine kinase } \\
\text { Inhibitor }\end{array}$ \\
\hline $\begin{array}{c}\text { Calcifediol } \\
\left(\text { Rayaldee }^{\mathrm{TM}}\right)\end{array}$ & 2016 & $2 / 4$ & II/III & $\begin{array}{l}\text { Vitamin D } \\
\text { analog }\end{array}$ \\
\hline
\end{tabular}

$* \mathrm{NDA}=$ New Drug Application, $* * A N D A=$ Abbreviated New Drug Application, $* * * B C S=$ Biopharmaceutics Classification System, $* * * *$ LFC $=$ Lipid Formulation Classification 


\section{Characterization of Lipid-based Drug Delivery System:}

\section{a. Physical analysis:}

The thermal behavior of the lipids during formulation is changed because lipid excipients have a complex chemical composition which tends to broad melting ranges [71]. Various thermal properties of lipids such as melting point, crystallization temperature, glass transition temperature, an exact determination of the solid fat content of the excipient versus temperature can be estimated using differential scanning calorimetry (DSC). X-ray diffraction (XRD) determines the crystallinity of a lipid excipient [72, 73].

\section{b. Chemical analysis:}

The exact composition of the ethers, esters, and fatty acid is evaluated by Gas Chromatography (GC) and High-Performance Liquid Chromatography (HPLC). The molecular weight of the fatty acid and the saturation of the hydrocarbon chain can be determined by saponification value and iodine-based assay respectively [74-76].

\section{c. In-vitro studies:}

Lipid digestion models are used for the in vitro evaluation of the lipid-based drug delivery system. The design of an in-vitro testing model is necessary to predict in-vivo performance. This model is also termed as a simulated lypolysis release testing model [77]. The fundamental principle involved in the test remains the system should run at a steady $\mathrm{pH}$ during a reaction that consumes or releases the hydrogen ion. If any deviation persists then, it is compensated by the addition of reagents.

The model typically consists of temperature-controlled vessels $\left(37^{\circ} \mathrm{C}\right)$ in which standard intestinal fluid is composed of bile salt, digestion buffer, and phospholipids. To initiate the digestion lipid-based formulation along with pancreatic along with colipase are added in the model. Once lipid digestion starts liberation of fatty acid and transit drop of $\mathrm{pH}$ is observed. The $\mathrm{pH}$ electrode coupled with the $\mathrm{pH}$-stat meter controller and auto burette quantifies the drop in $\mathrm{pH}$. An equimolar amount of sodium hydroxide is accurately calculated to titrate the released fatty acids by auto burette to restrict the drop of $\mathrm{pH}$ of digestion medium from a preset digestion $\mathrm{pH}$ value. Hence, the extent of the digestion can be predicted by the quantification of the rate of sodium hydroxide addition and considering the stoichiometric relationship between sodium hydroxide and fatty acids. 
It is reported that the concentration of bile salts, calcium, and lipase activity affects the digestion process $[78,79]$. The study suggested an in-vitro lipid digestion model for poorly water-soluble drugs [80]. The study has highlighted the significance of the in-vitro lipolysis model for optimizing the oral lipid-based formulations concerning systemic metabolism in the gut [81].

\section{d. In-vivo studies:}

The appropriate in-vivo study is implemented to estimate the impact of excipients on the bioavailability and pharmacokinetics of the drugs. Since the lipid-based formulation increases bioavailability by increasing the intestinal uptake it is very necessary to study the intestinal lymphatic system. Because of the unavailability of sufficient clinical data and variations in the method as well as the animal model used, the study became more complicated [82]. It was reported that the bioavailability of a lipid-based formulation of saquinavir mesylate (Fortovase ${ }^{\circledR}$ ) is enhanced up to three folds as compared to Invirase ${ }^{\circledR}$ (saquinavir is a hard gelatin capsule). The mesenteric lymph duct-canulated rat model was performed to identify the mechanism for the improved bioavailability for this formulation. The increased insolubilization and permeability of drugs lead to an increase in the bioavailability of the lipid-based formulation [83].

\section{Stability studies:}

There is a chance of lipid oxidation in the lipid-based drug delivery system [84]. To maintain physical and chemical stability, various strategies can be adopted which includes the use of saturated medium-chain triglycerides $\left(\mathrm{C}_{6}-\mathrm{C}_{12}\right)$, use of appropriate antioxidants like Vitamin $\mathrm{E}$ ( $\alpha$-tocopherol), butylated hydroxyanisole (BHA), butylated hydroxytoluene (BHT), and propyl gallate can perform synergistically with oxygen scavengers [85].

\section{Guidelines for design of lipid-based formulations:}

The lipid-based formulation is an important tool to formulate poorly soluble drugs and the design of such formulation is a more challenging task. Porter et al [86] outlined the seven guidelines for the design of drug delivery.

1. It is critically significant to sustain drug solubility in the lipid-based formulation, after dispersion and digestion. 
2. The properties of the colloidal species formed after dispersion in GI fluid are more important than the properties of the formulation in enhancing drug absorption.

3. A more significant proportion of lipids $(>60 \%)$ and a lower proportion of surfactant $(<30 \%)$ and cosolvent $(<10 \%)$ commence to more robust drug solubilization after dilution.

4. Medium-chain triglycerides lead to greater drug solubility and stability in formulations but long-chain triglycerides facilitate the more efficacious formation of bile salt lipid colloidal nature and tend to higher bioavailability.

5. After dispersion, the droplet formed by type IIIB SMEDDS is microscopic. However, the surfactant properties determine the nature of droplets, and undigestible surfactants generally result in higher bioavailability.

6. The use of two surfactants provides more efficient dispersions rather than a single one for type IV formulation.

7. Type IV formulations impart better drug solubility. However, they must be carefully designed with proper attention to ensure the precipitation of the drug does not occur after dispersion.

\section{Regulatory aspects:}

In a code of federal regulation, the FDA has published the list of substances generally recognized as a safe (GRAS). Apart from this Inactive Ingredient Guide (IIG) is maintained. Only the approved excipients can only be used in the market formulations [87]. GRAS and IIG act as a source of information from which the formulator can take the information regarding excipients to be used in the formulation. The essential quality and potential safety issues related to preclinical and clinical studies in common are the prime challenges supposed to encounter during the product launch of the lipid-based formulation. Overall drug stability and the absence of immunological to the oils and lipids are identified. The details explaining the use of lipid excipients, type of dosage form, drug release mechanism, and manufacturing procedure should be provided to the regulatory authority of their acceptability [88]. 


\section{Applications:}

1. Lipid-based drug delivery systems help to understand precisely the complex mechanism governing the interactions between lipid carriers and living cells. Therefore, they are typically safe, efficient, and specific carriers for the genes [89].

2. Lipid-based drug delivery system is applicable to efficiently deliver various types of drugs from new compounds to more recent new development for proteins, peptides, nucleic acids (DNA, sRNA), and cellular targeting [90-92].

3. Due to the versatility of lipid excipients, various formulation options like lipid suspensions, emulsions, microemulsions, mixed micelles, SEDDS, SMEDDS, liposomes are available to the formulator for increasing bioavailability, increase stability, and drug targeting [93].

4. The recent technology of the lipid-based drug delivery system not only mitigates the poor and variable gastrointestinal absorption but also reduces the influence of food in absorption.

5. Lipid-based nanotechnology is applicable for increasing therapeutic outcomes with the production of the multifunctional lipid-based nanoparticles [94].

\section{CONCLUSION AND FUTURE PROSPECTS:}

The drugs which come under BCS class 2 and 4 undoubtedly have less aqueous solubility which limits the oral bioavailability so the formulation of such drugs is a challenging task for formulation scientist to enhance oral bioavailability. Lipid-based drug delivery system is considered as the most promising and novel technology to enhance drug bioavailability by using various lipids excipients in the formulation. This review focused on different formulation technologies along with the characterization of the lipid-based formulations. Although the lipid-based drug delivery system is the most accepted technique for bioavailability enhancement there are few limitations regarding stability, manufacturing methods, and official database regarding the solubility of drugs in lipids. Hence, there is a need for proper regulatory guidelines for the lipid-based formulations. Further research work promptly has to be carried out to correlate between in-vitro and in-vivo studies. The present review summarized the various formulation approaches with the practical guidelines associated with the formulations which would be enormously helpful for the advancement of sophisticated technology to obtain safe and efficacious formulations. 


\section{ACKNOWLEDGEMENT:}

The authors would like to acknowledge faculty members of the department of pharmaceutics, Karnataka College of pharmacy for providing continuous suggestions regarding this review work.

\section{REFERENCES:}

1. Čerpnjak K, Zvonar A, Gašperlin M, Vrečer F. Lipid-based systems as a promising approach for enhancing the bioavailability of poorly water-soluble drugs. Acta Pharmaceutica. 2013;63(4):427-445.

2. Poonia N, Kharb R, Lather V, Pandita D. Nanostructured lipid carriers: versatile oral delivery vehicle. Future Science OA. 2016;2(3): FSO135.

3. Stegemann S, Leveiller F, Franchi D, de Jong H, Lindén H. When poor solubility becomes an issue: From early stage to proof of concept. European Journal of Pharmaceutical Sciences. 2007;31(5):249-261.

4. Lipinski C, Lombardo F, Dominy B, Feeney P. Experimental, and computational approaches to estimate solubility and permeability in drug discovery and development. Advanced Drug Delivery Reviews. 2001;46(13):3-26.

5. Lipinski C. Drug-like properties and the causes of poor solubility and poor permeability. Journal of Pharmacological and Toxicological Methods. 2000;44(1):235-249.

6. Yeramwar S, Patil S, Sharma P, Bhargava A. Design \& development of solid self micro-emulsifying osmotic drug delivery system for isradipine. Journal of Drug Delivery and Therapeutics. 2014:28-41.

7. Williams H, Trevaskis N, Charman S, Shanker R, Charman W, Pouton C et al. Strategies to Address Low Drug Solubility in Discovery and Development. Pharmacological Reviews. 2013;65(1):315-499.

8. Di L, Kerns E, Carter G. Drug-Like Property Concepts in Pharmaceutical Design. Current Pharmaceutical Design. 2009;15(19):2184-2194.

9. Di L, Fish P, Mano T. Bridging solubility between drug discovery and development. Drug Discovery Today. 2012;17(9-10):486-495.

10. Poovi G, Damodharan N. Lipid nanoparticles: A challenging approach for oral delivery of BCS Class-II drugs. Future Journal of Pharmaceutical Sciences. 2018;4(2):191-205.

11. Custodio J, Wu C, Benet L. Predicting drug disposition, absorption/elimination/transporter interplay, and the role of food on drug absorption. Advanced Drug Delivery Reviews. 2008;60(6):717-733.

12. Charalabidis A, Sfouni M, Bergström C, Macheras P. The Biopharmaceutics Classification System (BCS) and the Biopharmaceutics Drug Disposition Classification System (BDDCS): Beyond guidelines. International Journal of Pharmaceutics. 2019;566:264-281.

13. Porter C, Charman W. In vitro assessment of oral lipid-based formulations. Advanced Drug Delivery Reviews. 2001;50:S127-S147.

14. Charman W, Rogge M, Boddy A, Berger B. Effect of Food and a Monoglyceride Emulsion Formulation on Danazol Bioavailability. The Journal of Clinical Pharmacology. 1993;33(4):381-386.

15. Humberstone A, Porter C, Charman W. A physicochemical Basis for the Effect of Food on the Absolute Oral Bioavailability of Halofantrine. Journal of Pharmaceutical Sciences. 1996;85(5):525-529.

16. Kalepu S, Manthina M, Padavala V. Oral lipid-based drug delivery systems - an overview. Acta Pharmaceutica Sinica B. 2013;3(6):361-372.

17. Aungst B. Novel Formulation Strategies for Improving Oral Bioavailability of Drugs with Poor Membrane Permeation or Presystemic Metabolism. Journal of Pharmaceutical Sciences. 1993;82(10):979-987.

18. Kawabata Y, Wada K, Nakatani M, Yamada S, Onoue S. Formulation design for poorly water-soluble drugs based on biopharmaceutics classification system: Basic approaches and practical applications. International Journal of Pharmaceutics. 2011;420(1):1-10.

19. Loftsson T, Brewster M, Masson M. Role of Cyclodextrins in Improving Oral Drug Delivery. American Journal of Drug Delivery. 2004;2(4):261-275. 


\section{www.ijppr.humanjournals.com}

20. Perlman M, Murdande M, Gumkowski M, Shah T, Rodricks C, Thorntonmanning J et al. Development of a self-emulsifying formulation that reduces the food effect for torcetrapib. International Journal of Pharmaceutics. 2008;351(1-2):15-22.

21. Jaiswal P, Aggarwal G. Bioavailability enhancement of poorly soluble drugs by SMEDDS: a review. Journal of Drug Delivery and Therapeutics. 2013;3(1).

22. Pouton C. Formulation of poorly water-soluble drugs for oral administration: Physicochemical and physiological issues and the lipid formulation classification system. European Journal of Pharmaceutical Sciences. 2006;29(3-4):278-287.

23. Jannin V, Musakhanian J, Marchaud D. Approaches for the development of solid and semi-solid lipid-based formulations. Advanced Drug Delivery Reviews. 2008;60(6):734-746.

24. Müller R, Radtke M, Wissing S. Solid lipid nanoparticles (SLN) and nanostructured lipid carriers (NLC) in cosmetic and dermatological preparations. Advanced Drug Delivery Reviews. 2002;54:S131-S155.

25. Gershkovich P, Wasan K, Barta C. A Review of the Application of Lipid-Based Systems in Systemic, Dermal/ Transdermal, and Ocular Drug Delivery. Critical Reviews ${ }^{\mathrm{TM}}$ in Therapeutic Drug Carrier Systems. 2008;25(6):545-584.

26. Pavelić Ž, Škalko-Basnet N, Filipović-Grčić J, Martinac A, Jalšenjak I. Development and in vitro evaluation of a liposomal vaginal delivery system for acyclovir. Journal of Controlled Release. 2005;106(12):34-43.

27. Pouton C. Lipid formulations for oral administration of drugs: non-emulsifying, self-emulsifying, and 'selfmicro emulsifying' drug delivery systems. European Journal of Pharmaceutical Sciences. 2000;11:S93-S98.

28. Hauss D, Fogal S, Ficorilli J, Price C, Roy T, Jayaraj A et al. Lipid-Based Delivery Systems for Improving the Bioavailability and Lymphatic Transport of a Poorly Water-Soluble LTB4 Inhibitor. Journal of Pharmaceutical Sciences. 1998;87(2):164-169.

29. Kuentz M. Lipid-based formulations for oral delivery of lipophilic drugs. Drug Discovery Today: Technologies. 2012;9(2):e97-e104.

30. Kuentz M. Drug Absorption Modeling as a Tool to Define the Strategy in Clinical Formulation Development. The AAPS Journal. 2008;10(3):473-479.

31. Kuentz M, Nick S, Parrott N, Röthlisberger D. A strategy for preclinical formulation development using GastroPlus $^{\mathrm{TM}}$ as pharmacokinetic simulation tool and a statistical screening design applied to a dog study. European Journal of Pharmaceutical Sciences. 2006;27(1):91-99.

32. Gibson L. Lipid-based excipients for oral drug delivery. Drugs and the Pharmaceutical sciences. 2007 Jun $8 ; 170: 33$.

33. Poulton C, Porter C. Formulation of lipid-based delivery systems for oral administration: materials, methods, and strategies. Advanced Drug Delivery Reviews. 2008;60(6):625-637.

34. Michaelsen M, Wasan K, Sivak O, Müllertz A, Rades T. The Effect of Digestion and Drug Load on Halofantrine Absorption from Self-nano emulsifying Drug Delivery System (SNEDDS). The AAPS Journal. 2015;18(1):180-186.

35. Thomas N, Holm R, Garmer M, Karlsson J, Müllertz A, Rades T. Supersaturated Self-Nanoemulsifying Drug Delivery Systems (Super-SNEDDS) Enhance the Bioavailability of the Poorly Water-Soluble Drug Simvastatin in Dogs. The AAPS Journal. 2012;15(1):219-227.

36. Pouton C. Formulation of poorly water-soluble drugs for oral administration: Physicochemical and physiological issues and the lipid formulation classification system. European Journal of Pharmaceutical Sciences. 2006;29(3-4):278-287.

37. Holm R. Bridging the gaps between academic research and industrial product developments of lipid-based formulations. Advanced Drug Delivery Reviews. 2019;142:118-127.

38. Nanjwade B. Functions of Lipids for Enhancement of Oral Bioavailability of Poorly Water-Soluble Drugs. Scientia Pharmaceutica. 2011;79(4):705-727.

39. Tarr B, Yalkowsky S. Enhanced intestinal absorption of cyclosporine in rats through the reduction of emulsion droplet size. Pharmaceutical Research. 1989;06(1):40-43.

40. Singh B, Bandopadhyay S, Kapil R, Singh R, Katare O. Self-Emulsifying Drug Delivery Systems (SEDDS): Formulation Development, Characterization, and Applications. Critical Reviews ${ }^{\mathrm{TM}}$ in Therapeutic Drug Carrier Systems. 2009;26(5):427-451. 


\section{www.ijppr.humanjournals.com}

41. Lin JH, Chen W, King J. The effect of dosage form on oral absorption of L-365, 260, a potent CCK receptor antagonist in dogs. Pharm. Res. 1991;8:272.

42. Groves MJ. The self-emulsifying action of mixed surfactants in oil. Acta Pharmaceutica Suecica. 1976;13(4):361-72.

43. Gershkovich P, Hoffman A. Uptake of lipophilic drugs by plasma-derived isolated chylomicrons: linear correlation with intestinal lymphatic bioavailability. European journal of pharmaceutical sciences. 2005 Dec 1;26(5):394-404.

44. Khoo S, Humberstone A, Porter C, Edwards G, Charman W. Formulation design and bioavailability assessment of lipidic self-emulsifying formulations of halofantrine. International Journal of Pharmaceutics. 1998;167(1-2):155-164.

45. Palin KJ, Wilson CG. The effect of different oils on the absorption of probucol in the rat. Journal of pharmacy and pharmacology. 1984 Sep;36(9):641-3.

46. Collnot E, Baldes C, Wempe M, Hyatt J, Navarro L, Edgar K et al. Influence of vitamin E TPGS poly(ethylene glycol) chain length on apical efflux transporters in Caco-2 cell monolayers. Journal of Controlled Release. 2006;111(1-2):35-40.

47. Collnot E, Baldes C, Wempe M, Kappl R, Hüttermann J, Hyatt J et al. Mechanism of Inhibition of PGlycoprotein Mediated Efflux by Vitamin E TPGS: Influence on ATPase Activity and Membrane Fluidity. Molecular Pharmaceutics. 2007;4(3):465-474.

48. Christie WW. High-performance liquid chromatography and lipids: a practical guide. Oxford: Pergamon Press; $1-272$.

49. Strickley R. Solubilizing Excipients in Oral and Injectable Formulations. Pharmaceutical Research. 2004;21(2):201-230.

50. Humberstone AJ, Charman WN. Lipid-based vehicles for the oral delivery of poorly water-soluble drugs. Advanced drug delivery reviews. 1997 Apr 14;25(1):103-28.

51. Cao Y, Marra M, Anderson B. Predictive Relationships for the Effects of Triglyceride Ester Concentration and Water Uptake on Solubility and Partitioning of Small Molecules into Lipid Vehicles. Journal of Pharmaceutical Sciences. 2004;93(11):2768-2779.

52. Kaukonen A, Boyd B, Porter C, Charman W. Drug Solubilization Behavior During in Vitro Digestion of Simple Triglyceride Lipid Solution Formulations. Pharmaceutical Research. 2004;21(2):245-253.

53. Strickley R. Solubilizing Excipients in Oral and Injectable Formulations. Pharmaceutical Research. 2004;21(2):201-230.

54. Strickley RG. Currently marketed oral lipid-based dosage forms: drug products and excipients. Drugs and the Pharmaceutical sciences. 2007 Jun 8;170:1.

55. Millard JW, Alvarez-Nunez FA, Yalkowsky SH. Solubilization by cosolvents: Establishing useful constants for the log-linear model. International Journal of Pharmaceutics. 2002 Oct 1;245(1-2):153-66.

56. Yalkowsky SH. Solubility and solubilization in aqueous media. American Chemical Society; 1999.

57. Wakerly MG, Pouton CW, Meakin BJ, Morton FS. Self-emulsification of vegetable oil-nonionic surfactant mixtures: a proposed mechanism of action.

58. Pouton C. Formulation of self-emulsifying drug delivery systems. Advanced Drug Delivery Reviews. 1997;25(1):47-58.

59. Hauss DJ, editor. Oral lipid-based formulations: enhancing the bioavailability of poorly water-soluble drugs. CRC Press; 2007 Jun 8.

60. Cuiné J, Charman W, Pouton C, Edwards G, Porter C. Increasing the Proportional Content of Surfactant (Cremophor EL) Relative to Lipid in Self-emulsifying Lipid-based Formulations of Danazol Reduces Oral Bioavailability in Beagle Dogs. Pharmaceutical Research. 2007;24(4):748-757.

61. Grove M, Müllertz A, Pedersen GP, Nielsen JL. Bioavailability of seocalcitol: III. Administration of lipidbased formulations to minipigs in the fasted and fed state. European journal of pharmaceutical sciences. 2007 May 1;31(1):8-15.

62. Larsen DB, Joergensen S, Olsen NV, Hansen SH, Larsen C. In vivo release of bupivacaine from subcutaneously administered oily solution. Comparison with in vitro release. Journal of controlled release. 2002 May 17;81(1-2):145-54. 


\section{www.ijppr.humanjournals.com}

63. Gill KK, Kaddoumi A, Nazzal S. Mixed micelles of PEG2000-DSPE and vitamin-E TPGS for concurrent delivery of paclitaxel and parthenolide: enhanced chemosenstization and antitumor efficacy against non-small cell lung cancer (NSCLC) cell lines. European journal of pharmaceutical sciences. 2012 May 12;46(1-2):64-71. 64. Gursoy RN, Benita S. Self-emulsifying drug delivery systems (SEDDS) for improved oral delivery of lipophilic drugs. Biomedicine \& pharmacotherapy. 2004 Apr 1;58(3):173-82.

65. Zhang Y, Wang R, Wu J, Shen Q. Characterization and evaluation of self-micro emulsifying sustainedrelease pellet formulation of puerarin for oral delivery. International journal of pharmaceutics. 2012 May $10 ; 427(2): 337-44$.

66. Angelova MI, Dimitrov DS. Liposome electroformation. Faraday Discussions of the Chemical Society. 1986;81:303-11.

67. Zhao Y, Dai D, Lu C, Chen L, Lin M, Shen X et al. Epirubicin loaded with propylene glycol liposomes significantly overcomes multidrug resistance in breast cancer. Cancer Letters. 2013;330(1):74-83.

68. Jores K, Mehnert W, Drechsler M, Bunjes H, Johann C, Mäder K. Investigations on the structure of solid lipid nanoparticles (SLN) and oil-loaded solid lipid nanoparticles by photon correlation spectroscopy, field-flow fractionation, and transmission electron microscopy. Journal of Controlled Release. 2004 Mar 5;95(2):217-227.

69. Venishetty VK, Chede R, Komuravelli R, Adepu L, Sistla R, Diwan PV. Design and evaluation of polymercoated carvedilol loaded solid lipid nanoparticles to improve the oral bioavailability: a novel strategy to avoid intraduodenal administration. Colloids and Surfaces B: Biointerfaces. 2012 Jun 15;95:1-9.

70. Savla R, Browne J, Plassat V, Wasan KM, Wasan EK. Review and analysis of FDA approved drugs using lipid-based formulations. Drug development and industrial pharmacy. 2017 Nov 2;43(11):1743-58.

71. Hauss DJ. Oral lipid-based formulations. Advanced drug delivery reviews. 2007 Jul 30;59(7):667-676.

72. Demetzos C. Differential scanning calorimetry (DSC): a tool to study the thermal behavior of lipid bilayers and liposomal stability. Journal of liposome research. 2008 Jan 1;18(3):159-73.

73. Severino P, Pinho SC, Souto EB, Santana MH. Crystallinity of Dynasan ${ }^{\circledR} 114$ and Dynasan® 118 matrices for the production of stable Miglyol®-loaded nanoparticles. Journal of thermal analysis and calorimetry. 2012 Apr 1;108(1):101-8.

74. Zhou Q, Liu L, Zhang D, Fan X. Analysis of gemcitabine liposome injection by HPLC with evaporative light scattering detection. Journal of Liposome Research. 2012 Dec 1;22(4):263-9.

75. Li Z, Kozlowski BM, Chang EP. Analysis of aldehydes in excipients used in liquid/semi-solid formulations by gas chromatography-negative chemical ionization mass spectrometry. Journal of Chromatography A. 2007 Aug 10;1160(1-2):299-305.

76. Van de Voort FR, Sedman J, Emo G, Ismail AA. Rapid and direct iodine value and saponification number determination of fats and oils by attenuated total reflectance/Fourier transform infrared spectroscopy. Journal of the American Oil Chemists' Society. 1992 Nov 1;69(11):1118-23.

77. Porter CJH, Trevaskis NL, Charman WN. Lipids and lipid-based formulations: optimizing the oral delivery of lipophilic drugs. Nat Rev Drug Discov 2007;6:231-48.

78. Zangenberg NH, Müllertz A, Kristensen HG, Hovgaard L. A dynamic in vitro lipolysis model: I. Controlling the rate of lipolysis by continuous addition of calcium. European Journal of Pharmaceutical Sciences. 2001 Sep 1;14(2):115-22.

79. Zangenberg NH, Müllertz A, Kristensen HG, Hovgaard L. A dynamic in vitro lipolysis model: II: Evaluation of the model. European Journal of Pharmaceutical Sciences. 2001 Oct 1;14(3):237-44.

80. Christensen JO, Schultz K, Mollgaard B, Kristensen HG, Mullertz A. Solubilisation of poorly water-soluble drugs during in vitro lipolysis of medium-and long-chain triacylglycerols. European Journal of Pharmaceutical Sciences. 2004 Nov 1;23(3):287-96.

81. Dahan A, Hoffman A. Use of a dynamic in vitro lipolysis model to rationalize oral formulation development for poor water-soluble drugs: correlation with in vivo data and the relationship to intra-enterocyte processes in rats. Pharmaceutical research. 2006 Sep 1;23(9):2165-74.

82. Edwards GA, Porter CJ, Caliph SM, Khoo SM, Charman WN. Animal models for the study of intestinal lymphatic drug transport. Advanced drug delivery reviews. 2001 Aug 23;50(1-2):45-60.

83. Griffin B, O'Driscoll C. A comparison of intestinal lymphatic transport and systemic bioavailability of saquinavir from three lipid-based formulations in the anesthetized rat model. Journal of Pharmacy and Pharmacology. 2006;58(7):917-925. 


\section{www.ijppr.humanjournals.com}

84. Cannon JB. Chemical and physical stability considerations for lipid-based drug formulations. American Pharmaceutical Review. 2008;11(1):132.

85. Mitrus O, Żuraw M, Losada-Barreiro S, Bravo-Díaz C, Paiva-Martins F. Targeting antioxidants to interfaces: control of the oxidative stability of lipid-based emulsions. Journal of agricultural and food chemistry. 2019 Feb 27;67(11):3266-74.

86. Porter CJ, Pouton CW, Cuine JF, Charman WN. Enhancing intestinal drug solubilisation using lipid-based delivery systems. Advanced drug delivery reviews. 2008 Mar 17;60(6):673-91.

87. Koo OM, Varia SA. Case studies with new excipients: development, implementation and regulatory approval. Therapeutic delivery. $2011 \mathrm{Jul} ; 2(7): 949-56$.

88. Abdel-Mottaleb MM, Neumann D, Lamprecht A. Lipid nanocapsules for dermal application: a comparative study of lipid-based versus polymer-based nanocarriers. European Journal of Pharmaceutics and Biopharmaceutics. 2011 Sep 1;79(1):36-42.

89. Rawat M, Singh D, Saraf S, Saraf S. Lipid carriers: a versatile delivery vehicle for proteins and peptides. Yakugaku Zasshi. 2008 Feb 1;128(2):269-80.

90. Almeida AJ, Souto E. Solid lipid nanoparticles as a drug delivery system for peptides and proteins. Advanced drug delivery reviews. 2007 Jul 10;59(6):478-90.

91. Choi WJ, Kim JK, Choi SH, Park JS, Ahn WS, Kim CK. Low toxicity of cationic lipid-based emulsion for gene transfer. Biomaterials. 2004 Dec 1;25(27):5893-903.

92. Almeida AJ, Souto E. Solid lipid nanoparticles as a drug delivery system for peptides and proteins. Advanced drug delivery reviews. 2007 Jul 10;59(6):478-90

93. Kim DW, Kwon MS, Yousaf AM, Balakrishnan P, Park JH, Kim DS et al. Comparison of a solid SMEDDS and solid dispersion for enhanced stability and bioavailability of clopidogrel napadisilate. Carbohydrate polymers. 2014 Dec 19;114:365-74.

94. Buse J, El-Aneed A. Properties, engineering and applications of lipid-based nanoparticle drug-delivery systems: current research and advances. Nanomedicine. 2010 Oct;5(8):1237-60. 
www.ijppr.humanjournals.com

\begin{tabular}{|c|c|}
\hline 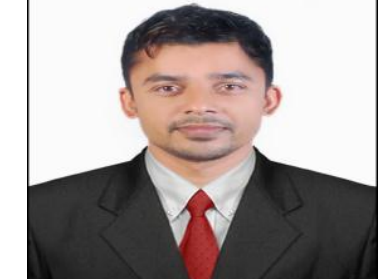 & $\begin{array}{l}\text { Author Name-Corresponding Author: Mr. Sachin Aryal } \\
\text { Author Affiliation: RGUHS } \\
\text { Author Address/Institute Address: } \\
\text { Karnataka college of pharmacy, Bangalore } 560064\end{array}$ \\
\hline & $\begin{array}{l}\text { Author Name: Mr. Roshan Gyawali } \\
\text { Author Affiliation: RGUHS } \\
\text { Author Address/Institute Address: } \\
\text { Karnataka college of pharmacy, Bangalore } 560064\end{array}$ \\
\hline & $\begin{array}{l}\text { Author Name: Mr. Yuvraj Regmi } \\
\text { Author Affiliation: RGUHS } \\
\text { Author Address/Institute Address: } \\
\text { Karnataka college of pharmacy, Bangalore } 560064\end{array}$ \\
\hline $\begin{array}{l}\text { He } \\
\text { hane }\end{array}$ & $\begin{array}{l}\text { Author Name: Dr. Beny Baby } \\
\text { Author Affiliation: RGUHS } \\
\text { Author Address/Institute Address: } \\
\text { Karnataka college of pharmacy, Bangalore } 560064\end{array}$ \\
\hline
\end{tabular}

